\title{
Oridonin enhances in vitro anticancer effects of lentinan in SMMC-7721 human hepatoma cells through apoptotic genes
}

\author{
TAO XU, FA JIN, KEREN WU, ZHIPENG YE and NING LI \\ Department of Hepatobiliary Surgery, The First Affiliated Hospital of Zhejiang Chinese Medical University, \\ Hangzhou, Zhejiang 310005, P.R. China
}

Received August 16, 2016; Accepted April 11, 2017

DOI: $10.3892 /$ etm.2017.5168

\begin{abstract}
The aim of the present study was to determine the ability of oridonin to enhance the anticancer activity of lentinan (LNT) in SMMC-7721 human hepatoma cells in vitro by using various techniques, including MTT, flow cytometry, quantitative PCR and western blot assays. The results demonstrated that $20 \mu \mathrm{g} / \mathrm{ml}$ was a non-toxic concentration of oridonin for L02 normal liver cells and SMMC-7721 cells, while 0-200 $\mu \mathrm{g} / \mathrm{ml}$ of LNT only had anti-proliferative effects on SMMC-7721 cells. LNT at 100 and $200 \mu \mathrm{g} / \mathrm{ml}$ inhibited the growth of SMMC-7721 cells by 22.8 and $60.0 \%$, respectively, and after addition of $20 \mu \mathrm{g} / \mathrm{ml}$ oridonin, the inhibitory rate of 100 and $200 \mu \mathrm{g} / \mathrm{ml} \mathrm{LNT}$ was increased to 47.2 and $80.7 \%$, respectively. Oridonin $(20 \mu \mathrm{g} / \mathrm{ml})+$ LNT $(200 \mu \mathrm{g} / \mathrm{ml})$-treated SMMC-7721 cells showed the highest apoptotic rate, which was $40.5 \pm 2.5 \%$, which was higher than that of cells treated with LNT only. LNT raised the mRNA and protein expression of caspase-3, -8 and -9 as well as B-cell lymphoma 2 (Bcl-2)-associated $\mathrm{X}$ protein, p53 and p21, while reducing the expression of $\mathrm{Bcl}-2$, $\mathrm{Bcl}$ extra large protein, epidermal growth factor (EGF) and EGF receptor expression in SMMC-7721 cells as compared to that in control cells. Treatment with $20 \mu \mathrm{g} / \mathrm{ml}$ oridonin and $200 \mu \mathrm{g} / \mathrm{ml} \mathrm{LNT}$ increased these changes of gene expression. From the obtained results, it may be concluded that oridonin raised the in vitro anti-cancer effects of LNT in SMMC-7721 cells. Oridonin may also be used as a sensitizing agent to increase the anticancer activity of LNT in vivo.
\end{abstract}

\section{Introduction}

LNT (lentinan) is a polysaccharide isolated from Shiitake (Lentinula edodes), which has pharmaceutical properties,

Correspondence to: Dr Ning Li, Department of Hepatobiliary Surgery, The First Affiliated Hospital of Zhejiang Chinese Medical University, 54 Youdian Road, Hangzhou, Zhejiang 310005, P.R. China

E-mail: lining006@126.com

Key words: oridonin, lentinan, SMMC-7721 cells, mRNA expression, protein expression including immunomodulatory, antitumor, anti-viral and anti-bacterial effects, with high efficacy and minimal side effects (1). LNT is efficient in the treatment of gastric, colon, breast and lung cancer, leading to prolonged survival time of patients. LNT is often used as immune enhancer in clinical applications and enhances curative effects and/or reduces side effects of other drugs if given in combination (2). For instance, LNT significantly enhanced the anticancer activity of cisplatin in the treatment of colon cancer (3). Furthermore, LNT increased the activation of bacillus Calmette-Guérin (BCG) pulmonary macrophages in guinea pigs and reduced systemic adverse reactions of BCG vaccine (4).

Oridonin is an ent-kaurene diterpenoid compound mainly isolated from Rhodamnia rubescens. A previous study has demonstrated that oridonin induces tumor cell apoptosis (5); furthermore, it sensitized liver cancer cell lines to radiotherapy in vitro, rendering it unique as a naturally occurring compound with a radiosensitization effect (6).

An ideal anticancer agent is a drug that induces differentiation and apoptosis of tumor cells. Previous clinical studies have focused on preparations based on their toxic effects on cancer cells, while the focus has shifted towards the development of substances which induce differentiation and apoptosis of cancer cells in recent years $(7,8)$. Unspecific cytotoxic effects of anticancer drugs are frequently associated with a significant negative impact on normal cells, while an apoptosis-inducing effect on cancer cells allows for selective targeting whilst avoiding any influence on normal cells. Certain biologically active chemical substances contained in plants have strong apoptosis-inducing effects on cancer cells, such as oridonin, an active component of Shiitake mushrooms (6).

Certain substances with cancer cell apoptosis-inducing effects that were extracted from plants have low toxicity and are safe to use, which enhances the quality of life of patients during treatment. While numerous natural anticancer drugs contained in plants have a lower efficacy than certain synthetic drugs, the combination of various natural products may have an improved therapeutic effect (9). Identification of a reasonable combination has become an important task in the field of natural product-based as anticancer treatments. The present study assessed how oridonin improves the anticancer effect of LNT in vitro with the aim of developing a novel combined anticancer treatment. By using various methods such as MTT, flow cytometry, reverse-transcription quantitative polymerase 
Table I. Sequences of primers used for polymerase chain reaction.

\begin{tabular}{lll}
\hline Gene & \multicolumn{1}{c}{ Forward primer } & \multicolumn{1}{c}{ Reverse primer } \\
\hline Caspase-3 & 5'-CAA ACT TTT TCA GAG GGG ATC G-3' & 5'-GCA TAC TGT TTC AGC ATG GCA-3' \\
Caspase-8 & 5'-CCC CAC CCT CAC TTT GCT-3' & 5'-GGA GGA CCA GGC TCA CTT A-3' \\
Caspase-9 & 5'-GGC CCT TCC TCG CTT CAT CTC-3' & 5'-GGT CCT TGG GCC TTC CTG GTA T-3' \\
Bax & 5'-AAG CTG AGC GAG TGT CTC CGG CG-3' & 5'-CAG ATG CCG GTT CAG GTA CTC AGT C-3' \\
Bcl-2 & 5'-CTC GTC GCT ACC GTC GTG ACT TGG-3' & 5'-CAG ATG CCG GTT CAG GTA CTC AGT C-3' \\
Bcl-xL & 5'-CCC AGA AAG GAT ACA GCT GG-3' & 5'-GCG ATC CGA CTC ACC AAT AC-3' \\
p53 & 5'-GCT CTG ACT GTA CCA CCA TCC-3' & 5'-CTC TCG GAA CAT CTC GAA GCG-3' \\
p21 & 5'-CTC AGA GGA GGC GCC ATG-3' & 5'-GGG CGG ATT AGG GCT TCC-3' \\
EGF & 5'-CAG GCC AGC CTC GTC TCA T-3' & 5'-GCC AAG CTC AGA AGG CTA C-3' \\
EGFR & 5'-TTT CTG GCA GTT GCT CCT C-3' & 5'-TCG GTG CTG TGC GAT TTA-3' \\
GAPDH & 5'-AGC CTT CTC CAT GGT CGT GA-3' & 5'-CGG AGT CAA CGG ATT TGG TC-3'
\end{tabular}

Bax, Bcl-2-associated X protein; Bcl-2, B-cell lymphoma 2; Bcl-xL, Bcl extra large protein; EGF, epidermal growth factor; EGFR, EGF receptor.

chain reaction (RT-qPCR) and western blot analysis the enhancing effect of oridonin on growth inhibition and apoptosis induction by LNT on hepatocellular carcinoma cells was assessed in vitro, in order to further establish a theoretical basis for animal experiments and even clinical application.

\section{Materials and methods}

Cell preparation. The L02 normal human liver cell line and the SMMC-7721 human hepatoma cell line were purchased from the Conservation Genetics CAS Kunming Cell Bank (Kunming, China). The cells were cultured in RPMI-1640 medium with $10 \%$ fetal bovine serum (FBS) (both from Gibco; Thermo Fisher Scientific, Inc., Waltham, MA, USA) in a humidified atmosphere containing $5 \% \mathrm{CO}_{2}$ at $37^{\circ} \mathrm{C}$. The medium was replaced 2-3 times a week and cells were passaged every 6-7 days.

MTT assay. The cells were seeded into 96-well culture plates (180 $\mu \mathrm{l}$ of a $1 \times 10^{4}$ cells $/ \mathrm{ml}$ suspension per well) and cultured for $24 \mathrm{~h}$ for attachment. Subsequently, oridonin or LNT (Shanghai Yuanye Biotechnology Co., Ltd., Shanghai, China) at the indicated concentrations were added to each well in a volume of $20 \mu \mathrm{l}$, followed by incubation for $48 \mathrm{~h}$. A total of $20 \mu 1$ MTT reagent solution $(5 \mathrm{mg} / \mathrm{ml}$; Amresco, Solon, $\mathrm{OH}$, USA) was then added. Following $4 \mathrm{~h}$ of further incubation, the supernatant fluid was aspirated and $150 \mu \mathrm{l}$ dimethyl sulfoxide was added per well. Subsequent to agitation for $30 \mathrm{~min}$, the optical density value of each well was determined at a wavelength of $540 \mathrm{~nm}$ by using an ELISA plate reader and the cell proliferation as well as inhibition rate were calculated (10).

Flow cytometric assay. After culture for $24 \mathrm{~h}$ with Sp-cyclic 3',5'-hydrogen phosphorothioate adenosine hydrate (Thermo Fisher Scientific, Inc.), cancer cells were incubated with $0.25 \%$ pancreatic enzymes (Thermo Fisher Scientific, Inc.) to digest and disperse cells. After cells were detached, they were added into medium with serum to neutralize the pancreatic enzymes. Subsequent to centrifugation at $1,500 \mathrm{xg}$ for $5 \mathrm{~min}$, supernatant fluid was abandoned and the cell precipitate was collected and washed with PBS, followed by addition of $1 \mathrm{ml} 75 \%$ ethanol to fix cells and incubation at $4{ }^{\circ} \mathrm{C}$ overnight. The concentration of cancer cells was adjusted to $5 \times 10^{5} / \mathrm{ml}$ and the cells were washed with PBS 3 times, after which $500 \mu$ l PBS containing $50 \mu \mathrm{g} / \mathrm{ml}$ ethidium bromide (Gibco; Thermo Fisher Scientific, Inc.), $100 \mu \mathrm{g} / \mathrm{ml}$ RNase and $0.2 \%$ Triton X-100 (CycleTEST ${ }^{\mathrm{TM}}$ PLUS kit; Becton Dickinson, Franklin Lakes, NJ, USA) were added. Subsequent to incubation for $30 \mathrm{~min}$ at $4^{\circ} \mathrm{C}$ in the dark, cells were detected with a flow cytometry instrument (Accuri C6; BD Biosciences, Franklin Lakes, NJ, USA) (11).

$R T-q P C R$ assay. Different groups of cells treated using the same method as MTT assay (100 or $200 \mu \mathrm{g} / \mathrm{ml} \mathrm{LNT} \mathrm{and/or}$ $20 \mu \mathrm{g} / \mathrm{ml}$ oridonin) were collected, total RNA was extracted with TRIzol reagent (Invitrogen; Thermo Fisher Scientific, Inc.) and complementary (c)DNA was prepared by using a reverse transcription kit (GE Healthcare, Little Chalfont, UK). PCR amplification (SuperScript ${ }^{\circledR}$ III Platinum ${ }^{\circledR}$ SYBR-Green ${ }^{\circledR}$ One-Step qRT-PCR kit; Thermo Fisher Scientific, Inc.) of cDNA was performed and GAPDH was used as a housekeeping gene. The primer sequences are shown in Table I. The reaction conditions were $50^{\circ} \mathrm{C}$ for $2 \mathrm{~min}$, then 40 cycles of $95^{\circ} \mathrm{C}$ for $30 \mathrm{sec}, 95^{\circ} \mathrm{C}$ for $5 \mathrm{sec}$ and $60^{\circ} \mathrm{C}$ for $34 \mathrm{sec}(12,13)$.

Western blot assay. Cells were collected and total protein was extracted using lysis buffer (Thermo Fisher Scientific, Inc.), followed by determination of the protein concentration via the bicinchoninic acid method (Bio-Rad Laboratories, Inc., Hercules, CA, USA). Protein $(30 \mu \mathrm{g})$ was subjected to SDS-PAGE (0.4\%) and transferred onto polyvinylidene difluoride membranes activated by methanol. Following blocking with $10 \%$ skimmed milk powder for $1 \mathrm{~h}$ at $25^{\circ} \mathrm{C}$, the membranes were incubated with the primary antibodies of caspase-3 (ab13847), caspase-8 (ab25901), caspase-9 (ab52298), Bax (ab32503), Bcl-2 (ab59348), Bcl-xL (ab32370), p53 (ab1431), p21 (ab188224), EGF (ab9695) and EGFR (ab52894) (all from Abcam, Cambridge, MA, USA) at a dilution of 1:1,500 at $4^{\circ} \mathrm{C}$ overnight, followed by washing 3 times with 

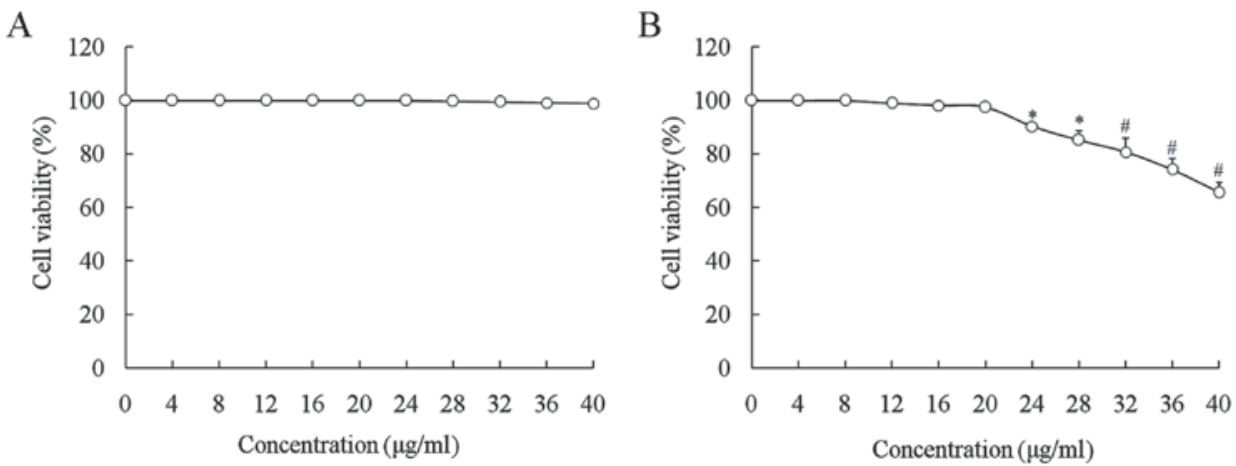

Figure 1. Effect of oridonin on the growth of (A) L02 human normal liver cell lines and (B) SMMC-7721 human hepatoma cells determined by an MTT assay. ${ }^{*} \mathrm{P}<0.05,{ }^{\#} \mathrm{P}<0.01$ vs. $0 \mu \mathrm{g} / \mathrm{ml}$ group.

A

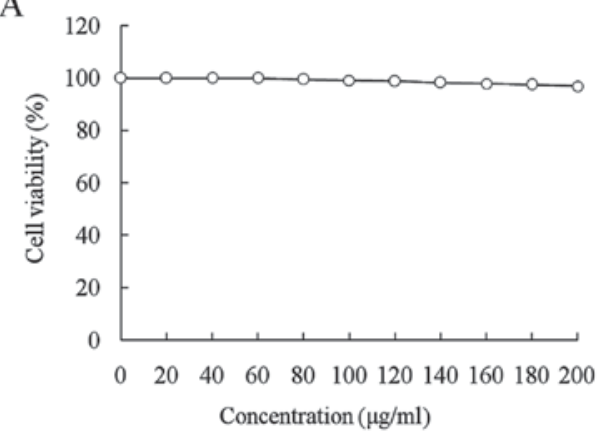

B

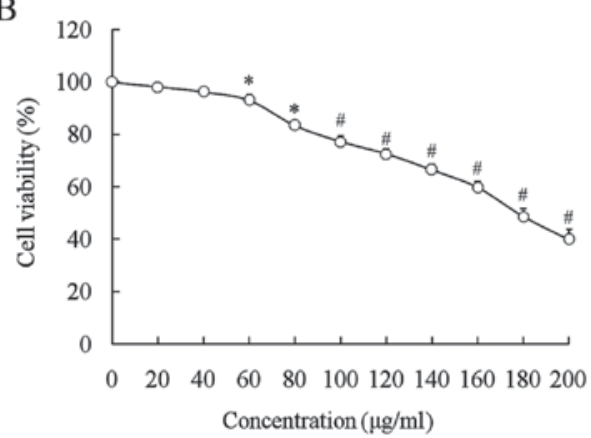

Figure 2. Effect of lentinan on the growth of (A) L02 human normal liver cell lines and (B) SMMC-7721 human hepatoma cells determined by an MTT assay. "P $<0.05,{ }^{\#} \mathrm{P}<0.01$ vs. $0 \mu \mathrm{g} / \mathrm{ml}$ group.

Tris-buffered saline containing Tween-20 (TBST) for $10 \mathrm{~min}$ each. Subsequently, the corresponding secondary antibodies (1:2,000 dilution, ab131368; Abcam) were added and allowed to react for $1 \mathrm{~h}$ at $25^{\circ} \mathrm{C}$, followed by washing three times with TBST for 10 min each, visualization of bands with enhanced chemiluminescence reagent (Thermo Fisher Scientific, Inc.) and capturing of X-ray film images. The same amount of $\beta$-actin (Santa Cruz Biotechnology, Inc., Dallas, TX, USA) was taken as the comparing standard used as a reference for probing of membranes (13).

Statistical analysis. Values are expressed as the mean \pm standard deviation. Significant differences between groups were determined by Duncan's multiple range test using SAS version 9.2 (SAS Institute Inc., Cary, NC, USA). P $<0.05$ was considered to indicate a statistically significant difference.

\section{Results}

Oridonin and LNT inhibit the growth of SMMC-7721, but not LO2 cells. The growth inhibitory effects of oridonin and LNT in L02 and SMMC-7721 cells were determined by an MTT assay (Figs. 1 and 2). Oridonin significantly decreased the growth of SMMC-7721 cells at concentrations of $>20 \mu \mathrm{g} / \mathrm{ml}$ $(\mathrm{P}<0.05)$, but not on L02 cells, while oridonin at $0-20 \mu \mathrm{g} / \mathrm{ml}$ had no toxic effect on normal or cancer cells (Fig. 1). LNT at $0-200 \mu \mathrm{l} / \mathrm{ml}$ decreased the growth of SMMC-7721 cells in a significantly concentration-dependent manner $(60-200 \mu \mathrm{g} / \mathrm{ml}$; $\mathrm{P}<0.05$ ), while it did not affect the growth of L02 normal cells (Fig. 2). Based on these results, oridonin was selected as a complementary drug to enhance the anticancer effect of LNT. LNT (100 and $200 \mu \mathrm{g} / \mathrm{ml})$ inhibited the proliferative rate of SMMC-7721 cells, and in the presence of oridonin $(20 \mu \mathrm{g} / \mathrm{ml})$, these inhibitory effects were substantially increased (Table II).

Oridonin and LNT induce apoptosis of SMMC-7721 cells. After treatment with LNT, the apoptotic rate (sub-G1 population of cells stained for their DNA content) of SMMC-7721 cancer cells was enhanced as compared with that of the control cells (3.0 $\pm 0.2 \%$; Fig. 3). Treatment with 100 and $200 \mu \mathrm{g} / \mathrm{ml}$ LNT led to an apoptotic rate of $15.5 \pm 1.2$ and $26.8 \pm 2.2 \%$, respectively, which was further increased by co-treatment with oridonin $(20 \mu \mathrm{g} / \mathrm{ml})$ to $22.1 \pm 1.7$ and $40.5 \pm 2.5 \%$, respectively.

Oridonin and LNT induce caspase-3, -8 and -9 mRNA and protein expression in SMMC-7721 cells. The expression of caspase-3, -8 and -9 in SMMC-7721 cells was significantly increased after treatment with 100 and $200 \mu \mathrm{g} / \mathrm{ml}$ LNT, and was further enhanced by co-treatment with oridonin $(20 \mu \mathrm{g} / \mathrm{ml})$. SMMC-7721 cells treated with oridonin $(20 \mu \mathrm{g} / \mathrm{ml})$ and $200 \mu \mathrm{g} / \mathrm{ml}$ LNT showed the highest increase in caspase-3, -8 and -9 mRNA and protein expression (Fig. 4).

Oridonin and LNT shift the balance of B-cell lymphoma 2 (Bcl-2), Bcl-2-associated X protein (Bax) and Bcl extra large protein $(B c l-x L)$ in SMMC-7721 cells. The mRNA and protein expression of Bax in SMMC-7721 cells was significantly increased after treatment with 100 and $200 \mu \mathrm{g} / \mathrm{ml} \mathrm{LNT}$, 
Table II. Growth inhibition of SMMC-7721 human hepatoma cells by oridonin and lentinan by an MTT assay.

\begin{tabular}{llr}
\hline Treatment & $\mathrm{OD}_{540}$ value & Inhibitory rate $(\%)$ \\
\hline Control & $0.430 \pm 0.003^{\mathrm{a}}$ & - \\
$\mathrm{LNT}(100 \mu \mathrm{g} / \mathrm{ml})$ & $0.332 \pm 0.014^{\mathrm{b}}$ & $22.8 \pm 2.2^{\mathrm{c}}$ \\
Oridonin $+\mathrm{LNT}(100 \mu \mathrm{g} / \mathrm{ml})$ & $0.227 \pm 0.012^{\mathrm{c}}$ & $47.2 \pm 4.1^{\mathrm{b}}$ \\
$\mathrm{LNT}(200 \mu \mathrm{g} / \mathrm{ml})$ & $0.172 \pm 0.007^{\mathrm{d}}$ & $60.0 \pm 3.8^{\mathrm{a}}$ \\
Oridonin $+\mathrm{LNT}(200 \mu \mathrm{g} / \mathrm{ml})$ & $0.083 \pm 0.005^{\mathrm{e}}$ & $80.7 \pm 4.4$
\end{tabular}

${ }^{\mathrm{a}-\mathrm{e}}$ Mean values with different letters in the same column indicate significant differences $(\mathrm{P}<0.05)$ according to Duncan's multiple-range test. Oridonin, $20 \mu \mathrm{g} / \mathrm{ml}$ oridonin; LNT, lentinan; $\mathrm{OD}_{540}$, optical density at $540 \mathrm{~nm}$.

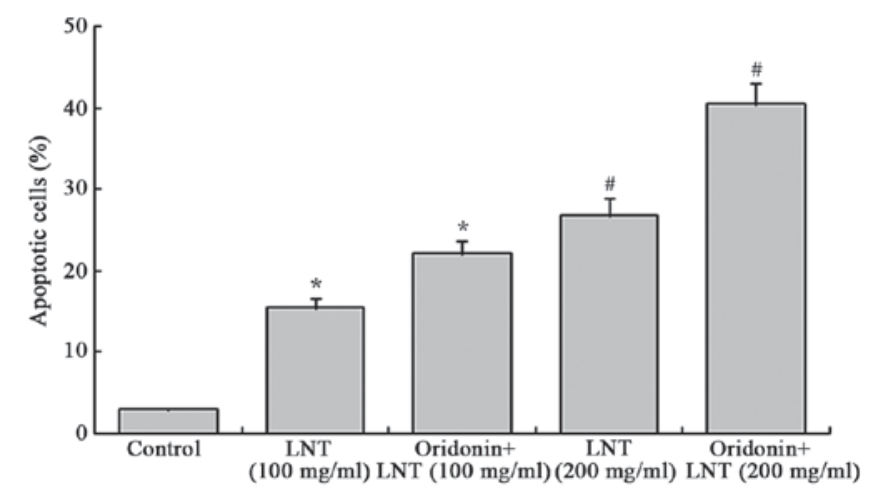

Figure 3. Apoptotic cells (sub-G1 phase of the cell cycle) of SMMC-7721 human hepatoma cells were quantified using a flow cytometer. " $\mathrm{P}<0.05$, ${ }^{\text {"P }}<0.01$ vs. control group. Oridonin, $20 \mu \mathrm{g} / \mathrm{ml}$ oridonin; LNT, lentinan.

which was further enhanced in the presence of oridonin. By contrast, the expression of $\mathrm{Bcl}-2$ and $\mathrm{Bcl}-\mathrm{xL}$ were decreased after treatment with 100 and $200 \mu \mathrm{g} / \mathrm{ml} \mathrm{LNT}$, and was further suppressed by co-treatment with oridonin (Fig. 5).

Oridonin and LNT increase p53 and $21 \mathrm{mRNA}$ and protein expression in SMMC-7721 cells. The mRNA and protein expression of p53 and p21 in $100 \mu \mathrm{g} / \mathrm{ml}$ LNT-treated cells were significantly enhanced compared to those in the control group and further increased in the $200 \mu \mathrm{g} / \mathrm{ml}$ LNT-treated cells; this effect was enhanced by co-treatment with oridonin (Fig. 6).

Oridonin and LNT decrease epidermal growth factor (EGF) and EGF receptor (EGFR) $m R N A$ and protein expression in SMMC-7721 cells. LNT at 100 and $200 \mu \mathrm{g} / \mathrm{ml}$ dose-dependently decreased the EGF and EGFR mRNA and protein expression in SMMC-7721 cells, which was further suppressed by oridonin treatment (Fig. 7).

\section{Discussion}

Induction of cancer cell apoptosis is an important strategy for the treatment of liver cancer. It is well known that a variety of cell signals mediated by receptors and signaling molecules are responsible for triggering liver cancer cell apoptosis, and a variety of proteases are involved in the signal conduction; it is a strictly regulated process involving a large variety
A

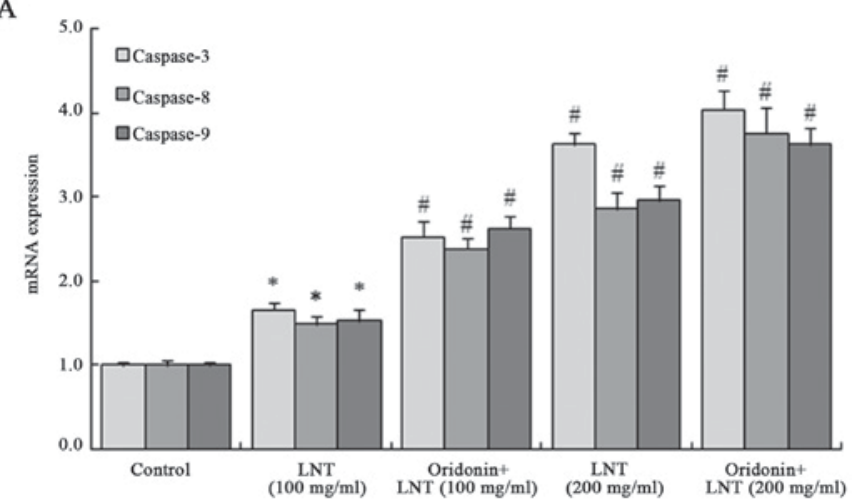

B
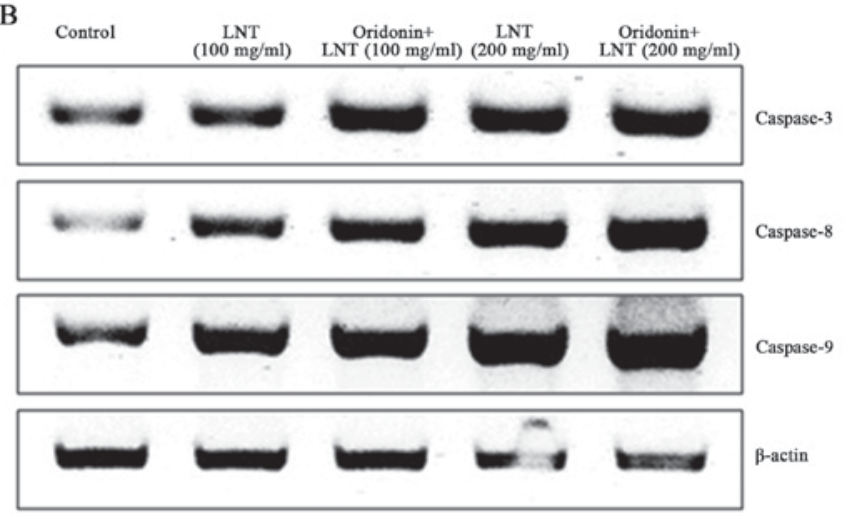

Figure 4. (A) mRNA and (B) protein expression of caspase-3, -8 and -9 in SMMC-7721 human hepatoma cells determined by reverse-transcription quantitative polymerase chain reaction and western blot assays, respectively. ${ }^{*} \mathrm{P}<0.05,{ }^{\text {"P }} \mathrm{P}<0.01$ vs. control group. Oridonin, $20 \mu \mathrm{g} / \mathrm{ml}$ oridonin; LNT, lentinan.

of genes. The protease caspase- 3 has a core role in signal conduction and execution of apoptosis (14). As a downstream event of the apoptotic cascade, its activation may occur via multiple pathways. Upon its activation through cleavage, e.g. by initiator caspase-9, caspase-3 carries out the programmed cell death by dismantling the cytoskeleton, and its activation is therefore desirable for inducing cancer cell apoptosis (15). Caspase- 8 is another core protease that may cause the caspase cascade reaction of cell apoptosis. In liver cancer cells, apoptosis via caspase- 3 and -8 activation has a central role and represents a downstream target for anticancer drugs, while these pathways may be deactivated in certain types of cancer cell (16). In the present study, caspase-3, -8 and -9 expression 
A

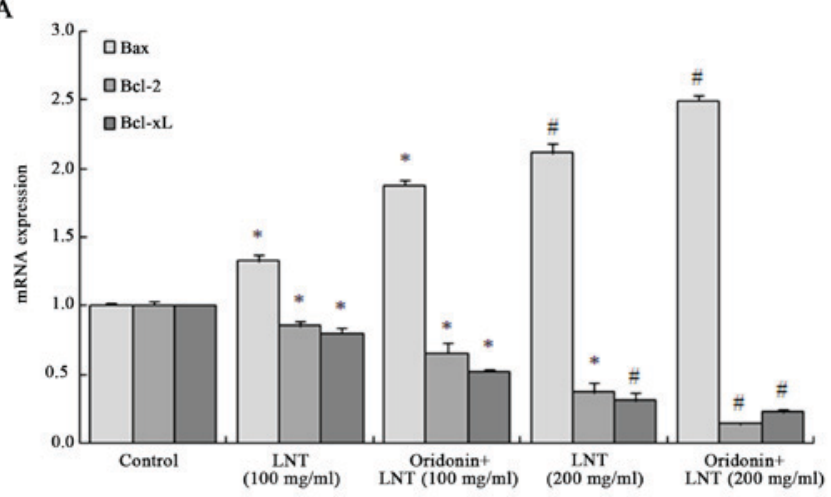

B

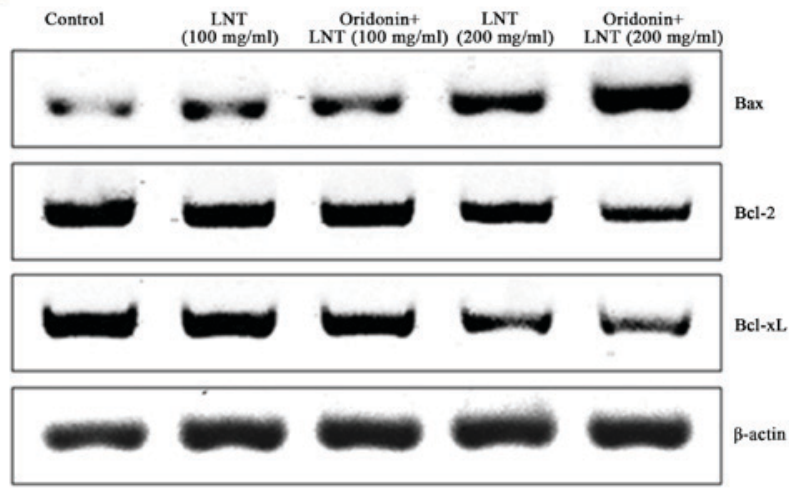

Figure 5. (A) mRNA and (B) protein expression of Bax, Bcl-2 and Bcl-xL in SMMC-7721 human hepatoma cells determined by reverse-transcription quantitative polymerase chain reaction and western blot assays, respectively. ${ }^{*} \mathrm{P}<0.05,{ }^{~} \mathrm{P}<0.01$ vs. control group. Oridonin, $20 \mu \mathrm{g} / \mathrm{ml}$ oridonin; LNT, lentinan; Bcl-2, B-cell lymphoma 2; Bax, Bcl-2-associated X protein; Bcl-xL, Bcl extra large protein.

A

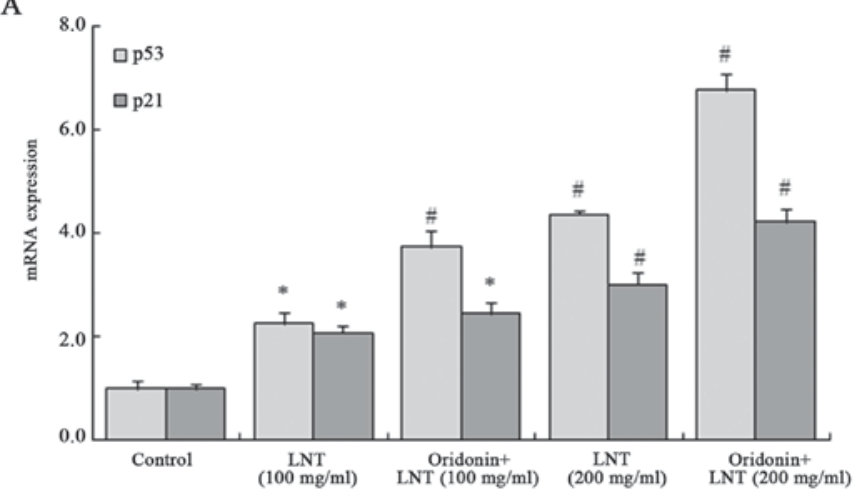

B
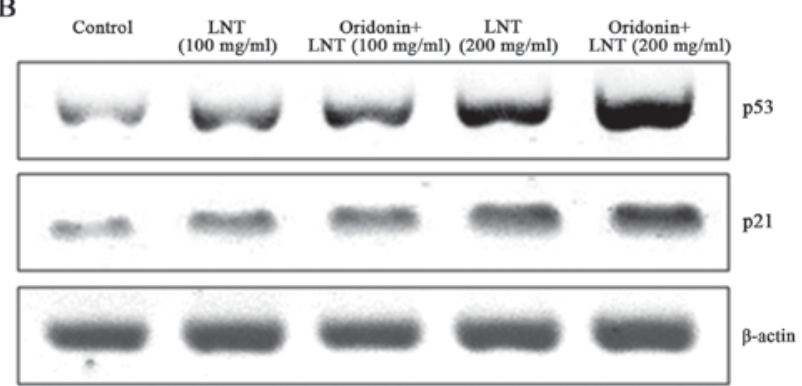

Figure 6. (A) mRNA and (B) protein expression of p53 and p21 in SMMC-7721 human hepatoma cells determined by reverse-transcription quantitative polymerase chain reaction and western blot assays, respectively. ${ }^{*} \mathrm{P}<0.05,{ }^{"} \mathrm{P}<0.01$ vs. control group. Oridonin, $20 \mu \mathrm{g} / \mathrm{ml}$ oridonin; LNT, lentinan.

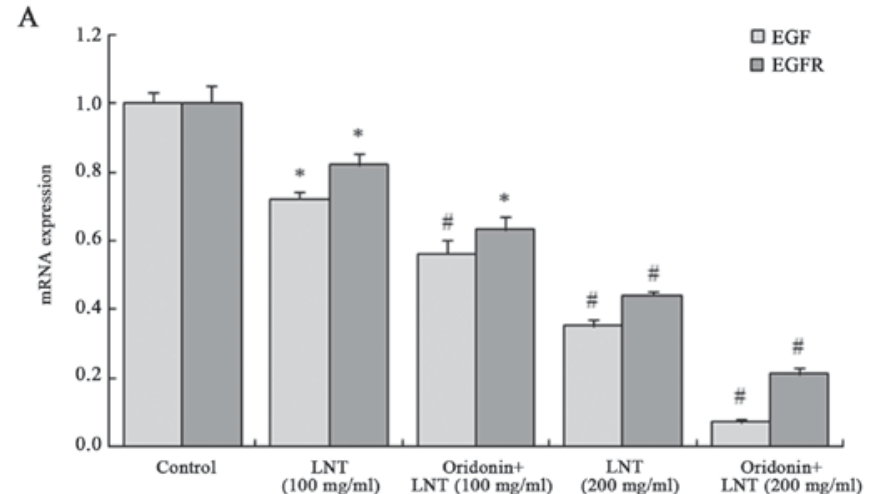

B

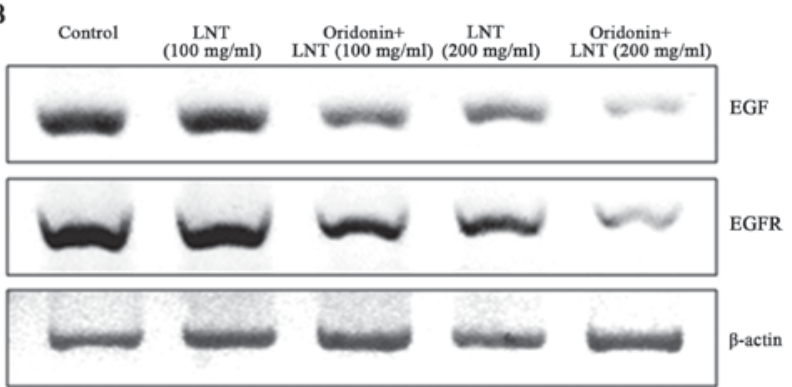

Figure 7. (A) mRNA and (B) protein expression of EGF and EGFR in SMMC-7721 human hepatoma cells determined by reverse-transcription quantitative polymerase chain reaction and western blot assays, respectively. ${ }^{*} \mathrm{P}<0.05,{ }^{\#} \mathrm{P}<0.01$ vs. control group. Oridonin, $20 \mu \mathrm{g} / \mathrm{ml}$ oridonin; LNT, lentinan; EGFR, epidermal growth factor receptor.

in cancer cells was increased by oridonin and LNT treatment, which was consistent with previous results (14).

The Bcl-2 family of apoptotic proteins has an important regulatory role in the process of caspase-3 activation $(16,17)$. As an anti-apoptotic member of the Bcl-2 family, Bcl-xL inhibits oligomers of apoptotic protease activating factor 1 (Apaf-1) molecules, resulting in loss of function of Apaf-1 and inhibition of the activation of caspase-9, which depends on Apaf-1 (18). Anti-apoptotic members of Bcl-2 family, which mainly exist in the outer membrane of mitochondria, may prevent mitochondria from releasing cytochrome $c$, thus inhibiting the activation of pro-caspase-9 (19). All pro-apoptotic Bcl-2 family members form miscellaneous dimers with Bcl-2, Bcl-xL, A1 and myeloid cell leukemia-1 via their BH3 domain, and therefore at least partly function by influencing anti-apoptotic Bcl-2 family members. Once pro-apoptotic Bcl-2 family members outnumber their anti-apoptotic counterparts, they induce the activation of caspases (20). In the present study, the drug combination could also raise Bax and reduce Bcl-2 and Bcl-xL expression compared with untreated cancer cells.

p53 causes apoptosis through the activation of caspases $(21,22)$. Following restoration of wild-type p53, activation of caspase- 3 and characteristic changes of cell apoptosis occurred in cells with a Fas defect, indicating that p53-dependent apoptosis directly activates caspases without mediation via Fas (23). Apoptosis-inhibiting factor Bcl-2 regulates apoptosis through forming a homodimer or heterodimers with Bax protein. When the $\mathrm{Bcl}-2 / \mathrm{Bax}$ ratio is high, apoptosis is inhibited, while apoptosis is induced if the ratio decreases below a certain threshold. The mechanism of Bcl-xL is similar 
to that of Bcl-2 (24). Silencing of Bcl-2 induces the activation of the p53-dependent apoptotic pathway. In p53 wild-type cancer cells, after p53 is activated, the expression of Bax increases with the quantity of cancer inhibitors, while Bcl-2 and Bcl-xL are simultaneously reduced, which shows that in the process of killing cancer cells by inhibitors, $\mathrm{p} 53$ induces apoptosis mainly through Bax/Bcl-2 and Bax/Bcl-xL pathways (25). In cancer cells, certain active substances may change the expression of p21 through p53, thus inducing the stagnation of the cell cycle. Increased expression of $\mathrm{p} 21$ and $\mathrm{p} 53$ is one of the indicators of apoptosis induction in cancer cells by certain substances (25). In the present study, oridonin and LNT combination exhibited a good anticancer effect, based on increased p53 and p21 expression.

Studies have shown that in the process of proliferation, stem cells secrete growth factors such as EGF and vascular endothelial growth factor to maintain their own growth and inhibit apoptosis. EGF and EGFR take part in the process of inducing cancer cell apoptosis (26). EGF is a growth factor with a large variety of functions and acts by combining with EGFR. Studies have shown that growth factors such as EGF promote the proliferation of stem cells and maintain the balance of normal cells (27). EGFR is a member of the ErbB receptor family on the cell surface, which is involved in cellular processes, including proliferation, growth, migration and invasion (28). Studies have also found that EGFR adjusts EGF-mediated cancer cell proliferation through saliva acidification $(28,29)$. In addition, EGFR inhibitors were shown to induce cancer cells to express UL16 binding protein 1 in order to enhance their sensitivity to natural killer cells (29). In the present study, oridonin and LNT were observed to inhibit growth of cancer cells by reducing EGF and EGFR expression.

In the present study MTT, flow cytometry, RT-qPCR and western blot assays revealed that LNT had a potent and dose-dependent anticancer effect on SMMC-7721 cancer cells, while a non-toxic concentration of oridonin increase these in vitro anticancer effects of LNT. It is concluded that oridonin may be used as a drug to increase the anticancer effect of LNT.

\section{References}

1. Kupfahl C, Geginat G and Hof H: Lentinan has a stimulatory effect on innate and adaptive immunity against murine Listeria monocytogenes infection. Int Immunopharmacol 6: 686-696, 2006.

2. Hou XJ and Chen W: Optimization of extraction process of crude polysaccharides from wild edible $\mathrm{BaChu}$ mushroom by response surface methodology. Carbohyd Polym 72: 67-74, 2008.

3. Murata T, Hatayama I, Kakizaki I, Satoh K, Sato K and Tsuchida S: Lentinan enhances sensitivity of mouse colon 26 tumor to cis-diamminedichloroplatinum (II) and decreases glutathione transferase expression. Jpn J Cancer Res 87: 1171-1178, 1996.

4. Drandarska I, Kussovski V, Nikolaeva S and Markova N: Combined immunomodulating effects of BCG and Lentinan after intranasal application in guinea pigs. Int Immunopharmacol 5: 795-803, 2005.

5. Huang HL, Weng HY, Wang LQ, Yu CH, Huang QJ, Zhao PP, Wen JZ, Zhou H and Qu LH: Triggering Fbw7-mediated proteasomal degradation of c-Myc by oridonin induces cell growth inhibition and apoptosis. Mol Cancer Ther 11: 1155-1165, 2012.

6. Wang H, Yu HS and Xue HW: Radio sensitization effect of oridonin on HepG2 in vitro. Med J Qi Lu 22: 339-342, 2007.
7. Mullard A: Pioneering apoptosis-targeted cancer drug poised for FDA approval. Nat Rev Drug Discov 15: 147-149, 2016.

8. Denisenko TV, Sorokina IV, Gogvadze V and Zhivotovsky B: Mitotic catastrophe and cancer drug resistance: A link that must to be broken. Drug Resist Updat 24: 1-12, 2016.

9. O'Connor SE: Plant biochemistry. Fighting cancer while saving the mayapple. Science 349: 1167-1168, 2015.

10. Zhao X, Wang Q, Li GJ, Chen F, Qian Y and Wang R: In vitro antioxidant, anti-mutagenic, anti-cancer and anti-angiogenic effects of Chinese bowl tea. J Funct Food 7: 590-598, 2014.

11. Zhao X, Qian Y, Zhou YL, Wang R, Wang Q and Li GJ: Pu-erh tea has in vitro anticancer activity in TCA 8113 cells and preventive effects on buccal mucosa cancer in U14 cells injected mice in vivo. Nutr Cancer 66: 1059-1069, 2014.

12. Suo H, Zhao X, Qian Y, Sun P, Zhu K, Li J and Sun B: Lactobacillus fermentum Suo attenuates $\mathrm{HCl} /$ ethanol induced gastric injury in mice through its antioxidant effects. Nutrients 8: $155,2016$.

13. Livak KJ and Schmittgen TD: Analysis of relative gene expression data using real-time quantitative PCR and the 2(Delta Delta C(T)) method. Methods 25: 402-408, 2001.

14. Wong RS: Apoptosis in cancer: From pathogenesis to treatment. J Exp Clin Cancer Res 30: 87, 2011.

15. O'Donovan N, Crown J, Stunell H, Hill AD, McDermott E, O'Higgins N and Duffy MJ: Caspase 3 in breast cancer. Clin Cancer Res 9: 738-742, 2003.

16. Rodríguez-Berriguete G, Galvis L, Fraile B, de Bethencourt FR, Martínez-Onsurbe P, Olmedilla G, Paniagua R and Royuela M: Immunoreactivity to caspase-3, caspase-7, caspase-8, and caspase-9 forms is frequently lost in human prostate tumors. Hum Pathol 43: 229-237, 2012.

17. Tsujimoto Y: Role of $\mathrm{Bcl}-2$ family proteins in apoptosis: Apoptosomes or mitochondria? Gene Cell 3: 697-707, 1998.

18. Swanton E, Savory P, Cosulich S, Clarke P and Woodman P. $\mathrm{Bcl}-2$ regulates a caspase-3/caspase-2 apoptotic cascade in cytosolic extracts. Oncogene 18: 1781-1787, 1999.

19. Park HJ, Jeon YK, You DH and Nam MJ: Daidzein causes cytochrome c-mediated apoptosis via the Bcl-2 family in human hepatic cancer cells. Food Chem Toxicol 60: 542-549, 2013.

20. Willis SN, Chen L, Dewson G, Wei A, Naik E, Fletcher JI, Adams JM and Huang DC: Proapoptotic Bak is sequestered by Mcl-1 and Bcl-xL, but not Bcl-2, until displaced by BH3-only proteins. Gene Dev 19: 1294-1305, 2005.

21. Xu SY, Xiao DJ, Luan YZ, Wang YS, Wang L and Shi K: Regulatory mechanism of cell cycle block and apoptosis in p53 mutated gastric cancer cells during cisplatin stress. J Shandong Univ (Health Sci) 46: 478-480, 2008.

22. Moulin M, Carpentier S, Levade T and Arrigo AP: Potential roles of membrane fluidity and ceramide in hyperthermia and alcohol stimulation of TRAIL apoptosis. Apoptosis 12: 1703-1720, 2007.

23. Fuchs EJ, Mckenna KA and Bedi A: p53-dependent DNA damage-induced apoptosis requires Fas/APO-1-independent activation of CPP32beta. Cancer Res 57: 2550-2554, 1997.

24. Klostergaard J, Leroux ME, Auzenne E, Khodadadian M, Spohn W, Wu JY and Donato NJ: Hyperthermia engages the intrinsic apoptotic pathway by enhancing upstream caspase activation to overcome apoptotic resistance in MCF-7 breast adenocarcinoma cells. J Cell Biochem 98: 356-369, 2006.

25. Woo SM, Choi YK, Kim AJ, Cho SG and Ko SG: p53 causes butein-mediated apoptosis of chronic myeloid leukemia cells. Mol Med Rep 13: 1091-1096, 2016.

26. Hollmann G, Linden R, Giangrande A and Allodi S: Increased p53 and decreased p21 accompany apoptosis induced by ultraviolet radiation in the nervous system of a crustacean. Aquat Toxicol 173: 1-8, 2016.

27. Deng W, Gu L, Li X, Zheng J, Zhang Y, Duan B, Cui J, Dong J and Du J: CD24 associates with EGFR and supports EGF/EGFR signaling via RhoA in gastric cancer cells. J Transl Med 14: 32, 2016.

28. Appert-Collin A, Hubert P, Crémel G and Bennasroune A: Role of ErbB receptors in cancer cell migration and invasion. Front Pharmacol 6: 283, 2015.

29. Yen HY, Liu YC, Chen NY, Tsai CF, Wang YT, Chen YJ, Hsu TL, Yang PC and Wong CH: Effect of sialylation on EGFR phosphorylation and resistance to tyrosine kinase inhibition. Proc Natl Acad Sci USA 112: 6955-6960, 2015. 